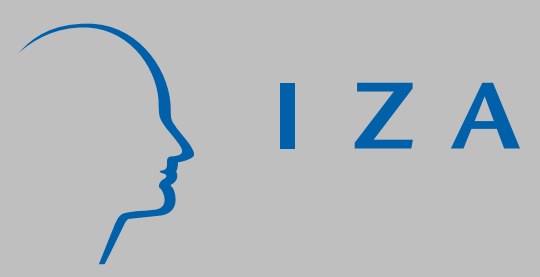

IZA DP No. 740

Evaluating the Labor Market Performance of Veterans Using a Matched Comparison Group Design

Barry T. Hirsch

Stephen L. Mehay

March 2003 


\title{
Evaluating the Labor Market Performance of Veterans Using a Matched Comparison Group Design
}

\author{
Barry T. Hirsch \\ Trinity University and IZA Bonn \\ Stephen L. Mehay \\ U.S. Naval Postgraduate School \\ Discussion Paper No. 740 \\ March 2003
}

\author{
IZA \\ P.O. Box 7240 \\ D-53072 Bonn \\ Germany \\ Tel.: +49-228-3894-0 \\ Fax: +49-228-3894-210 \\ Email: iza@iza.org
}

This Discussion Paper is issued within the framework of IZA's research area Evaluation of Labor Market Policies and Projects. Any opinions expressed here are those of the author(s) and not those of the institute. Research disseminated by IZA may include views on policy, but the institute itself takes no institutional policy positions.

The Institute for the Study of Labor (IZA) in Bonn is a local and virtual international research center and a place of communication between science, politics and business. IZA is an independent, nonprofit limited liability company (Gesellschaft mit beschränkter Haftung) supported by the Deutsche Post AG. The center is associated with the University of Bonn and offers a stimulating research environment through its research networks, research support, and visitors and doctoral programs. IZA engages in (i) original and internationally competitive research in all fields of labor economics, (ii) development of policy concepts, and (iii) dissemination of research results and concepts to the interested public. The current research program deals with (1) mobility and flexibility of labor, (2) internationalization of labor markets, (3) welfare state and labor market, (4) labor markets in transition countries, (5) the future of labor, (6) evaluation of labor market policies and projects and (7) general labor economics.

IZA Discussion Papers often represent preliminary work and are circulated to encourage discussion. Citation of such a paper should account for its provisional character. A revised version may be available on the IZA website (www.iza.org) or directly from the author. 


\title{
ABSTRACT \\ Evaluating the Labor Market Performance of Veterans Using a Matched Comparison Group Design*
}

\begin{abstract}
A key concern in estimating the effect of military service on civilian earnings is bias from unmeasured differences between military veterans and nonveterans. The effects of activeduty service are estimated using the 1986 and 1992 Reserve Components Surveys, which permit a matched comparison between reservists who are veterans and reservists without active-duty service. Because military entrance requirements are identical for the reserves and active duty, estimated treatment effects embody control for selection by the military and selection by workers for a form of military service. Results are presented for officers and enlisted personnel and by race and era of service. The average impact of active-duty service on civilian earnings is 3 percent among the reservist population, but this average reflects treatment effects of essentially zero for enlisted personnel and 10 percent for officers. Among white enlisted personnel, veteran effects are negative but small. Treatment effects for African-American veterans average about 5 percent. Vietnam-era white draftees are found to have suffered an approximate 5 percent wage penalty and volunteers little penalty, but estimates from the reservist sample are likely to understate negative effects from Vietnamera service.
\end{abstract}

JEL Classification: J3

Keywords: veterans, civilian earnings, matched comparison group

Corresponding author:

Barry T. Hirsch

Department of Economics

Trinity University

San Antonio, TX 78212

USA

Tel.: +1 8506443586

Fax: +1850644 4535

Email: bhirsch@trinity.edu

\footnotetext{
* The authors thank Jeff Biddle, Mike Greenwood, Paul Hogan, Madeline Zavodny, the Coeditor, and two anonymous referees for helpful comments. Dennis Mar and Melissa Potter provided excellent computing assistance. The views expressed are solely those of the authors.
} 


\section{Introduction}

The effect of military service on the civilian labor market performance of veterans has long been a topic of interest among economists and other social scientists. The issue is one of some consequence, given the importance of military service as a bridge to civilian work experience for many young men and women, the special importance of military service among African-American males, and the 1990s military drawdown that increased the flow from military to civilian employment.

Previous studies have examined evidence on veterans from all of the major war-time periods during which conscription was used, and from the All-Volunteer Force (AVF) period that began in 1973. The earliest studies on veteran earnings implicitly characterize military service as a treatment effect and assume exogenous selection. Economic theory suggests that the matching of workers to occupations and employers is not random. Studies that fail to account for occupational choice and military selection may provide biased estimates of the effects of military service. Yet the few studies that account for selection do not provide a completely clear picture of the effects of military service. Some contain estimation strategies whose reliability can be questioned (i.e., uncertain internal validity), while others rely on small or non-representative samples from which results may not be generalized (uncertain external validity). ${ }^{1}$

Shortcomings in previous studies stem primarily from limitations in readily available labor market surveys -- the Current Population Survey (CPS) and Census for draft-era and AVF veterans and the National Longitudinal Survey of Youth (NLSY) for AVF veterans. The CPS and Census offer large veteran samples, but provide little information on individual military histories or worker abilities and preferences. No information is included on whether the individual was drafted or volunteered or whether he was an officer or enlistee. The NLSY provides extensive military background information and includes AFQT scores, but suffers from small sample sizes and only permits analysis of AVF veterans.

The purpose of this study is to exploit an alternative source of information on veterans that remedies some of the deficiencies inherent in the Census, CPS, and NLSY. Compared to methods that control for selectivity using explicit modeling and identification of the selection process, this study uses a matched 
comparison group design to obtain causal inferences. The study uses a unique data set -- the Reserve Components Surveys (RCS) -- to control for unmeasured skills and preferences. The RCS consists of civilians in the labor force also affiliated with the military's Selected Reserve Components. Reservists include both veterans of the active-duty military and nonveterans. Because individuals linked by reserve affiliation are more likely to have similar abilities and preferences than are randomly selected individuals, our design controls for many unobserved background attributes that affect enlistment decisions. Equally important, the reservist sample controls for military selection, because eligibility and selection requirements are the same for the active military and the reserves. ${ }^{2}$ These data allow us to exploit what may be largely exogenous variation in veteran status to obtain reliable measures of the return to military service among reservists and, as suggested subsequently, perhaps for the wider population of veterans. Moreover, the RCS provides reasonably large sample sizes for both the draft-era and AVF periods and extensive information on one's military history, including rank, branch, tenure, training, and occupation. ${ }^{3}$

In what follows, we examine wage differentials between veteran and nonveteran reservists. We investigate a number of issues addressed in the prior literature. These include differences in veteran effects by race, the effects of military service during the Vietnam-era conscription and draft lottery periods, and veteran effects for volunteers during the AVF period. Unlike much of the previous literature, we distinguish between veteran effects on civilian earnings for officers and enlisted personnel.

\section{Background}

The development of the literature on veterans' earnings has paralleled in many ways that of the far larger literature on returns to schooling. Studies on educational returns have progressed from assuming that educational attainment is exogenous to the application of statistical controls for self selection, the use of

1. An exception to this generalization is a recent study by Angrist (1998), with which our study is most similar in design. Angrist develops a data set of military applicants, linked to Social Security earnings records, and compares the earnings of veterans with earnings among military applicants who did not serve.

2. Requirements are the same within branch. Some variation exists across branch of service and over time.

3. Mehay and Hirsch (1996) use the 1986 RCS to study the effects of military service among female reservists. Using standard regression analysis, they find a significant wage penalty among female veteran reservists compared to nonveteran reservists, in contrast to results from the CPS and NLSY that indicate few differences among women. They conclude that female veterans have positive unmeasured endowments, controlled for in the RCS but not the NLSY or CPS, owing in part to binding quotas on female recruitment. The low payoff to military service among women may result from limitations on the types of military occupations in which they had been allowed to serve prior to the 1990s. The authors do not examine evidence on male reservists. 
siblings and twins data, and the use of instruments that identify exogenous variation in schooling. ${ }^{4}$ In the literature on veterans, few studies have applied techniques to control for the unobserved heterogeneity that may bias estimates of the returns to military status. Exceptions include Angrist (1989, 1990, 1998); Angrist and Krueger (1994), Phillips et al. (1992); and Bryant et al. (1993).

Mangum and Ball (1989) review the literature that treats veteran status as exogenous. Extensive research on draft-era veterans and a smaller literature on AVF service (mostly using the NLSY) have failed to reach a consensus on the effects of military service on civilian earnings. Despite several clear empirical patterns, concerns about selection bias make it difficult to draw firm conclusions from this work.

Bryant et al. (1993) explicitly model selection bias in their study examining enlistment decisions and civilian earnings of AVF youth from the NLSY." They estimate a "Maddala-Lee" two-regime switching model in which their military enlistment equation includes, among other things, AFQT, attitude toward the military, and family members with a military background. Meaningful identification is achieved through inclusion in the enlistment equation (and exclusion from the wage equations) variables that are defined at the time each person is of military enlistment age (i.e., age of enlistment or the average at ages 18-20 for nonenlistees). Results indicate that male AVF veterans earned 1.7 percent less than they would have absent military service, and that nonveterans would have realized a 7.9 percent wage penalty had they served in the military. Penalties for military service are largest for white males and college graduates. Their selection variables are insignificant, suggesting that selection bias may be of limited importance during the AVF period.

Phillips et al. (1992) follow NLSY respondents from 1979 through 1984, allowing measurement of military earnings during veterans' tours of duty and civilian earnings following completion of their tours. The authors find that earnings are higher for veterans during their time in the military than they are for nonveterans during the same period, suggesting that the decision to join the military is based on one's expected earnings during as well as after military service. ${ }^{6}$ The earnings of white and black veterans drop after completion of their enlistment, but blacks still earn more than their peers who never served. Civilian age-earnings profiles

4. For recent surveys, see Angrist and Krueger (1999) and Card (1999).

5. Bryant and Wilhite (1990) find no selection bias in a study of veterans in the NLSY, but do not display the methodology or results of the selection bias test. 
for whites are steeper for veterans, who overtake their nonveteran counterparts within two years of discharge. The coefficients of the selectivity variables indicate positive selection for blacks and negative for whites.

Angrist (1998) compares the earnings of applicants who serve in the military with those who do not serve. $^{7}$ This strategy is likely to control for the most important selection factors by individuals in choosing military service. In addition to the matched comparison group and regression approaches, Angrist exploits information from the military "mis-norming" of applicant exams between 1976 and 1980 to obtain IV estimates of the effects of military service. Angrist concludes that military service during the AVF era tends to reduce earnings for whites while modestly increasing earnings among nonwhites. Military service is estimated to have positive effects on employment and school attainment. In contrast to our use of the RCS, where military standards are the same for active duty and reserve duty, the applicant sample used by Angrist may not adequately control for selection by the military. As noted by Angrist, however, the military uses prescreening tests to discourage clearly unqualified persons from applying.

Although there is some disagreement on the effect of military service during Vietnam, most studies indicate that the earnings of veterans from this period tend to lag behind their nonveteran peers, often many years after the end of the war. Using March CPS data, Berger and Hirsch (1983) find a small overall penalty for Vietnam-era veterans during the $1968-77$ period, with an earnings advantage for earlier cohorts of veterans and a nontrivial disadvantage for later cohorts, and more positive veteran effects among less educated than among more educated men. Schwartz (1986), using data from the March 1980 CPS for males ages 27-40, concludes that Vietnam veterans earn less than nonveterans and realize lower returns to schooling. Jackson (1986) uses the NLS Young Men's Cohort for 1976 and 1981 and finds lower wages for white veterans of higher ability, but no effect on black veterans' wages.

Angrist (1990) provides an insightful and often-cited analysis of the effects of military service on

6. Angrist (1998) likewise finds higher military earnings among active-duty personnel than among similar military applicants who do not serve.

7. For use of rejected applicants as a control group, see Bound's (1989) analysis of Social Security disability insurance (DI). Bound argues that comparing labor market outcomes of applicants accepted and rejected for DI provides an upper-bound estimate of disincentive effects since rejected applicants are, on average, healthier. For a comprehensive discussion and references, see Bell et al. (1995), who construct and analyze control groups comprising withdrawals, screen-outs and no-shows of job training programs. As in our analysis, their intent is to mitigate selection bias by using a comparison group in which individuals have revealed themselves to have many of the same difficult-to-measure characteristics as do those in the treatment group. 
Vietnam-era veterans. He estimates the impact of service during the draft lottery period (1970-72) on Social Security earnings for the years 1981-1984. Information on date of birth and the random assignment of draft lottery numbers is exploited as an instrument to obtain estimates of military treatment effects largely free of selection bias. He estimates that draft-eligible individuals earn about 3 percent less than those who were draftineligible. When the estimates are adjusted for the probability of serving in the armed forces, the projected penalty to whites at risk of the draft rises to 15 percent, while the wage effect for nonwhites is insignificant.

Angrist's (1990) analysis, however, is not without (inherent) limitations, many of which are discussed in his paper. It strictly applies only to those drafted during the two years during which the draft lottery was in effect and not to the earlier non-lottery draft period or the subsequent all-volunteer period. Although he would like to have had random assignment to treatment and control groups, some individuals with high lottery numbers (i.e., draft ineligibles) volunteered, while some with low numbers (draft eligibles) were not called and did not serve. It is not clear whether adjustment for the probability of service accurately maps the observed differential between those who were draft eligible and ineligible into an unbiased measure of the treatment effect. ${ }^{8}$ For these reasons, further study using an alternative dataset and method of analysis may provide insight into the effects of military service during the Vietnam era. That being said, our matched comparison group approach is best suited for measuring the effects of military service among those whose service is voluntary and is unlikely to provide unbiased estimates for Vietnam-era service.

\section{Estimation Methods Using a Matched Comparison Group}

\section{A. Selection and Measurement of Treatment Effects}

Selection arises as an issue first because recruits choose the military over other alternatives. Selection occurs further because military applicants must meet physical, mental, and moral standards to be eligible for enlistment and must meet job performance standards to be eligible for reenlistment. If the selection factors that explain veteran status are correlated with earnings, their omission from a wage equation may bias

8. Bound et al. (1995) examine the instrumental variable approach used by Angrist to deal with the endogeneity of veteran status. The appropriateness of IV estimation for identifying average treatment effects (with specific reference to the draft lottery analysis) is examined by Heckman (1997). A subsequent exchange between Heckman and Angrist and Imbens is contained the Fall 1999 issue of the Journal of Human Resources. 
estimates of the effect of active-duty military service on earnings. ${ }^{9}$

The research literature attempts to measure the causal effect of serving in the active-duty military on subsequent civilian earnings. It is convenient to think of this veteran effect as a "treatment effect". It is important to specify for what group the treatment effect is being estimated. Letting $\Delta$ be the causal effect of active-duty military service on civilian earnings, measured as a change in the log wage, then designate:

$\Delta_{1}=$ the treatment effect among randomly selected workers

$\Delta_{2}=$ the treatment effect among randomly selected veterans

$\Delta_{3}=$ the treatment effect among randomly selected veteran reservists

The parameter $\Delta_{1}$ is of least interest, since a sizable share of the population either would not volunteer for military service or would be rejected by the military were they to volunteer. Such a parameter would be of interest were the U.S. to adopt a lottery draft without exemptions and no exclusion by the military. The treatment effect $\Delta_{2}$ is of the most general interest since this measures the average treatment effect among those treated (this is the focus in Angrist 1998). It should closely approximate the effect among those likely to be treated, absent major changes in military selection or the size of the military. In this paper, we estimate veteran-nonveteran wage differences among military reservists, which should approximate $\Delta_{3}$, the average treatment effect among treated reservists. For reasons discussed below, we expect our measure of $\Delta_{3}$ to provide an approximation of $\Delta_{2}$ that may be preferable to OLS estimates of $\Delta_{2}$ derived from the CPS, NLSY, or other standard data sources covering the general population of civilians.

Let $E$ represent the expectations operator, $W$ the log of hourly earnings, $V$ veteran status, $N$ nonveteran status, $R$ reserve status, and $X$ measured worker characteristics. To estimate $\Delta$ directly we must measure what is not directly observable, the average difference between the observed earnings of veterans and what those same individuals would have earned had they not had active-duty military service. What we typically estimate, however, is the average difference in $(\log )$ earnings between veterans and nonveterans, conditional on measured characteristics, or:

$$
E\left[W_{V} \mid X, V=1\right]-E\left[W_{N} \mid X, V=0\right]
$$

This measure is not equivalent to the parameter of interest, $\Delta_{2}$, which corresponds to

9. Selection arises further in that veterans represent members of the armed forces who have left active-duty service. 


$$
E\left[W_{V} \mid X, V=1\right]-E\left[W_{N} \mid X, V=1\right] .
$$

The second term in (2) -- what veterans would have earned had they not had active-duty service -- is not observed. Equation (1) provides an unbiased measure of (2) only if nonveteran earnings would have been equivalent for veterans and nonveterans, conditional on measured $X^{\prime} s$. That is, if

$$
E\left[W_{N} \mid X, V=1\right]-E\left[W_{N} \mid X, V=0\right]=0,
$$

then estimates based on (1) are equivalent to (2). If the expression (3) is positive, implying that veterans would have earned more as nonveterans than do those who are nonveterans, then estimates of the veteran (treatment) effect are overstated, and vice versa.

The RCS sample provides substantial control for heterogeneity and selection factors whose omission may bias standard wage equation estimates of the veteran effect. For reasons discussed below, we expect the bias or unobservable difference in nonveteran earnings shown in (3) to be smaller (in absolute value) among the population of reservists than among the larger population of all employed males. That is,

$$
\left|E\left[W_{N} \mid X, V=1, R=1\right]-E\left[W_{N} \mid X, V=0, R=1\right]\right|<\left|E\left[W_{N} \mid X, V=1\right]-E\left[W_{N} \mid X, V=0\right]\right| .
$$

Again, this expression states that the earnings of reservist nonveterans more closely approximate what reservist veterans would have earned had they not served in active duty than does the same calculation among a general population not restricted to reservists. If the left-hand side term of the inequality in (4) is zero, we obtain an unbiased measure of $\Delta_{3}$ (equation (3) is satisfied and (1) and (2) are equivalent).

If treatment effects of active duty service are identical for reservists and nonreservists, then an unbiased estimate of $\Delta_{3}$ provides an unbiased measure of $\Delta_{2}$. As a general rule, however, an unbiased measure of $\Delta_{3}$ need not provide an unbiased measure of $\Delta_{2}$, the parameter of interest in most prior studies. We can think of reasons why $\Delta_{2}$ and $\Delta_{3}$ might differ, although not substantially. If training in the reserves were to provide skills that replicate those received on active duty, then $\Delta_{3}<\Delta_{2}$. The reservist veteran differential would be less than the economy-wide differential (which in standard data sets is close to zero) or the differential exclusively among nonreservists (not estimated in the literature).

The assumption that $\Delta_{3}$ approximates $\Delta_{2}$ follows automatically as the percentage of military veterans who enter the reserves increases, the distinction between $\Delta_{2}$ and $\Delta_{3}$ collapsing altogether if all veterans were to enter and remain in the reserves. Examination of data on annual accessions to the reserves, the percentage of 
these who were veterans, and the outflow of personnel from the active-duty military indicates that nearly 40 percent of veterans joined the reserves during the mid-1980s (data were provided to us by the Defense Manpower Data Center). Grissmer et al. (1994) find the probability of joining the selected reserve within six years of separation for 1984 active duty enlisted veterans is 41 percent for Army veterans, 34 percent for Navy veterans, and 12 percent for Marine Corps and Air Force veterans. For officers, the probabilities were over 40 percent for the Army, Navy, and Marine Corps, and 21 percent for Air Force veterans. In an earlier study, Marquis and Kirby (1989) estimated that over one-third of those separating from the active Army eventually joined the reserves. ${ }^{10}$

The principal basis for our use of the RCS reservist sample is that it controls for the most important forms of selection. Because entrance standards for the reserve and active forces are identical, all RCS respondents are eligible to serve on active duty. These entrance standards are mainly based on mental ability tests (AFQT), education, moral background (criminal record, drug use, etc.), and medical tests. Hence, veteran-nonveteran differences in these important characteristics are minimized in the RCS, whereas in a sample of the full civilian population assignment to the treatment group is based partly on these characteristics, many of which are unobserved by the researcher. A related source of selection bias is controlled in the RCS because of the similar preferences for the military shared by all reservists. In a sample of the larger population, preferences and alternative opportunities are major unobservables that explain why most otherwise qualified youth do not apply to the military. ${ }^{11}$

There exist less obvious forms of military selection in the full population, but of limited applicability among reservists. A key aspect of the enlistment decision is the use of enforceable long-term contracts. Those who choose the military and complete their contract are on average less quit-prone than those who reject enlistment. The RCS data mitigate potential bias from such unobservables because reservists who are

10. Whatever the precise figure for the time period corresponding to our RCS data, willingness to serve in the reserves is likely to be affected inversely by the robustness of the civilian labor market and the probability of one's reserve unit being activated. A news article examining a more recent period (Myers 2000) cites figures from the Army Reserve indicating that the percentage of those leaving the Army who say they would consider joining the reserves declined from 41 percent in 1997 to only 21 percent in 2000.

11. It is of course difficult to present direct evidence on unobservables. The RCS data set, however, does contain several variables (but with incomplete coverage) that can be considered as unobservables in standard data sets. As discussed subsequently (see Table 1), active-duty military service by reservists' fathers is similar for veteran and nonveteran reservists. The same is true for AFQT scores, available for a small subsample of the RCS. 
nonveterans also must commit to a long-term contract (generally six years).

Because the reservist sample provides a natural control for selection by individuals into the military, $\Delta_{3}$ is more likely to be a good predictor of $\Delta_{2}$ during periods when active-duty service is largely voluntary than for the Vietnam-era or other periods with involuntary service. The RCS includes veterans and nonveterans choosing to serve in the reserves. Nonveterans choosing reserve service (and remaining in the reserves through 1986 and 1992) may not provide the ideal comparison group for those with involuntary active-duty service. Nor are veterans in the reserves during 1986 and 1992 likely to be representative of those who were drafted into active duty, or volunteered in expectation of being drafted.

A further consideration for the RCS sample is whether time spent serving in the reserves affects civilian earnings. The literature suggests that the impact of reserve service on non-reserve earnings is small (Grissmer et al. 1989; Mehay 1991). Even if reserve service time affects earnings, it should impact all reservists. There is little reason to expect the veteran-nonveteran differential to be affected.

Finally, most studies have not dealt with the potential error in the self-reported veteran status variable in standard labor surveys. Individuals who leave before the expiration of their obligation (attriters) are not viewed as veterans (U.S. Department of Veterans Affairs 1989). Error typically involves an over-reporting of veteran status by survey respondents. This reporting error will bias estimated veteran effects toward zero, assuming that the veteran treatment effect for attriters is less than for true veterans. In the RCS data veterans must have been eligible to reenlist on active duty in order to qualify for the reserves, thus attriters are excluded from the data set, minimizing the potential for measurement error from this source. ${ }^{12}$

Despite the numerous advantages of the RCS data in controlling for major unobservables, pretreatment differences between veterans and nonveterans may remain. Despite their shared preferences for the military, reservist veterans chose a full-time military lifestyle that includes migrating from their home area, whereas reservist nonveterans chose part-time military participation and staying in their home area (with some

12. This argument assumes that we want to measure the value of completed military service, rather than the average effect of enlistment. Attrition rates are nontrivial, hovering around 30 percent-35 percent during the AVF period (U.S. GAO 1997). But most attriters leave the military quickly during "boot camp" within the first week(s) of service. They have not received military training and have not worked in a military job. They are eligible neither for veterans' benefits nor the reserves. As of 1980, the definition of a veteran in the decennial Census is intended to exclude those who have 
risk of activation and deployment outside the area). Such selection has an indeterminate bias on the veterannonveteran wage differential. Those who choose active-duty service may expect unusually high wages following military training or from a geographical move and/or have unusually low home area civilian opportunities. Those foregoing active-duty service may expect few gains from military training and mobility or have good home area opportunities. Hence, earnings observed among nonveteran reservists, $E\left[W_{N} \mid X, V=0\right.$, $R=1$ ], may overstate or understate earnings that would have been available to veterans had they foregone active service, but retained a willingness to move, $E\left[W_{N} \mid X, V=1, R=1\right]$. With forces working in opposite directions within a relatively homogenous population, the net bias may be small.

\section{B. Method of Estimation}

The arguments above suggest that the RCS data are well suited for a matched comparison group design in which the earnings of reservist veterans are compared to those of matched reservist nonveterans. Matching methods have received much recent attention from economists. ${ }^{13}$ Matching techniques in which each veteran is paired with a "similar" nonveteran provide a treatment effect estimate in which the weighting function is made explicit, in this case weights based on veteran characteristics. A regression framework, by contrast, creates a unimodal weighting function that is a combination of veteran and nonveteran characteristics (Angrist and Krueger 1999).

The major way in which veterans and nonveterans in the RCS differ is age, veteran reservists tending to be older than are nonveteran reservists. A natural approach then is to measure how earnings differ between reservist veterans and reservist nonveterans of the same age. Explicit matching on age controls for what is an important earnings determinant and provides an estimate of the average treatment effect based on the age distribution of veterans (the treatment group). The matching approach can be thought of as a variant of statistical imputation methods (Rubin 1987). The treatment group (veterans) has earnings imputed through a selected procedure (e.g., propensity score matching, hot deck matching). The treatment effect is then measured by the difference in means between the actual earnings of the treatment group and the matched or predicted earnings of the group based on the imputation procedure.

served on active duty less than 24 months (Cowper et al. 1994). Even were we able to observe attriters (they are not in the reserves), they are likely to differ in unmeasured ways from those who complete service. 
The first method of comparison we employ is the use of an age-adjusted mean wage differential, Age- $\Delta$, based on mean differences within age groups. This effectively matches veterans to all nonveterans of the same age. This is a natural metric for comparison, given the assumption that age is the only relevant difference between veterans and nonveterans in the reservist sample. The measure is obtained by taking the difference in log wages between the veteran and nonveteran reservists by age, and then averaging using the veteran sample age proportions as weights. That is,

$$
\text { Age }-\Delta=\Sigma_{\mathrm{V}}\left[W_{V}\left|V=1-W_{N}\right| V=0\right]_{\text {Age }},
$$

where $W_{V}$ and $W_{N}$ are mean log wages by age for veterans and nonveterans, the term in brackets is the mean difference by age, and $\Sigma_{\mathrm{V}}$ represents the averaging of differences using veteran age proportions.

We supplement our matching measures with regression analysis in which veteran wage differentials are estimated from earnings functions with "sparse" and "standard" specifications. Our sparse specification includes only age (linear, squared, and cubic terms) and a veteran dummy. This measures provides a natural counterpart to the measure $A g e-\Delta$, albeit one with a different weighting function. The standard wage equation includes measured premarket demographic and skill variables - schooling, potential experience (including years in the military), part-time status, race, ethnicity, and sample year. If none of the included regressors were correlated with veteran status, then the standard regression would provide an appropriate estimate of the veteran treatment effect. It can be argued, however, that even this specification is too dense, including outcome variables such as schooling and part-time status that may be affected by military service (for evidence, see Angrist 1993). We have argued that age is the principal difference between veteran and nonveteran reservists and, thus, the measures adjusting only for age are emphasized. Regressions with standard controls are included for purposes of comparison. We do not present estimates based on dense specifications including such variables as marital status, number of children, industry, occupation, and public employment. ${ }^{14}$ Control for public sector status is particularly inappropriate since the federal government, U.S. Postal Service, and some state and local governments give preference in hiring to veterans (or veterans from

13. For surveys and references, see Angrist and Krueger (1999) and Heckman, LaLonde, and Smith (1999). 14. Regression equations that include marital status, children, and part-time have little effect on results. Specifications that control for sector (with private sector industry and public sector dummies) produce veteran-nonveteran differentials 
war-time periods), preferences that may be regarded as part of the return to military service.

A natural counterpart to $A g e-\Delta$, the age-adjusted mean difference, is a matching estimator based exclusively on age. In work not shown, we conducted multiple hot-deck imputations, with each veteran randomly matched to same-aged nonveteran donors. The difference between veterans' actual wage and the matched nonveteran wage provides a measure of the veteran wage differential. Not surprisingly, the hot-deck matching estimates of the veteran treatment effect are virtually equivalent to the age-adjusted mean differences. Hence, they are not shown.

As a final measure of the veteran effect, we examine propensity score matching estimators. A logit equation with age, age-squared, age-cubed, and race is used to predict the likelihood of veteran status. Observations are ordered into deciles from low to high based on their propensity score, measuring the conditional probability of veteran status. The imputation procedure then matches each veteran with the wage of a nonveteran, selected randomly from among those with a similar propensity score (i.e., within the same decile). The veteran treatment effect is measured by the mean difference between veterans' actual log wages and their counterfactual nonveteran wage, based on the imputed wage from matched nonveterans. The imputation procedure is conducted for 100 rounds, effectively creating 100 data sets. Presented subsequently is the mean wage differential (and standard deviation) across the 100 data sets.

Propensity score methods are attractive where there is high dimensionality among the predictors, making exact matching problematic, or where selection bias is important and one has identified an appropriate prediction equation (see Heckman, Ichimura, Todd, 1998). Neither case holds here. Matching exclusively on age is straightforward (i.e., low dimension). Moreover, apart from age, there appear to be few important differences among reservists (measurable in our database) that determine veteran status. Thus, the propensity score estimator in this application provides few benefits, while at the same time producing a measure of the veteran wage gap that controls less precisely for age than do measures that match explicitly on age. ${ }^{15}$

that are slightly lower. Using the RCS, we are unable to control for tenure on the current civilian job, region, city size or, apart from a small subset of our sample, AFQT scores.

15. Angrist and Krueger (1999) and Heckman, LaLonde, and Smith (1999) provide surveys of estimation methods. Rosenbaum and Rubin (1983) show that if matching on X is valid, then matching on the basis of a propensity score - the probability of selection into a treatment group - is also valid. This converts the problem of multidimensional matching into a feasible single-dimensional matching exercise. This theorem requires several strong assumptions, including the 


\section{Veteran-Nonveteran Wage Differentials in the RCS}

\section{A. The RCS Database}

Veteran-nonveteran earnings differentials are estimated using the 1986 and the somewhat smaller 1992

Reserve Components Surveys (RCS). The RCS provides data on reservists who are members of the Selected

Reserve (SELRES) Components. ${ }^{16}$ The population of SELRES members was 1.13 million in 1986 and 1.11 million in 1992 (U.S Department of Defense 1986, 1992).

Our RCS sample is restricted to male reservists ages 21-59 working in civilian wage and salary jobs (including those self-employed). These restrictions result in an estimation sample of 51,475, of whom 41,413 are enlisted personnel and 10,062 are officers. ${ }^{17}$ Veterans, who comprise 59 percent of the enlisted and 71 percent of the officer reservist samples, are restricted to those who report at least two years of active-duty service. ${ }^{18}$ The full RCS samples contain over 75,000 reservists, as compared to our estimation sample of 51,475. The sample loss for the enlisted sample, on which we focus attention, occurs as follows. The enlisted sample prior to restrictions is 59,664 . The following groups were then deleted sequentially: female reservists, who are oversampled in the RCS (leaving 51,338), Coast Guard reservists $(50,101)$, those with missing age $(49,870)$, and those below age 21 or above $59(47,907)$. Among the 47,907 "eligible" for our analysis of enlisted personnel, the sample was reduced to 41,665 following deletion of those with missing earnings or hours worked (most of whom are believed to be not employed) and finally to the

assumption that the probability of selection is known and not estimated. Dehejia and Wahba $(1998,1999)$ reanalyze data used by LaLonde (1986), in which he obtained a disturbingly wide range of estimates using alternative methods. Dehejia and Wahba conclude that use of propensity score methods, which use treatment group weights, substantially narrows the range and provides estimates close to the experimental results. Smith and Todd (2000) review this evidence and conclude that propensity score methods are not a cure-all, displaying sensitivity to the choice of variables included in the participation equation. For a careful analysis comparing direct matching and propensity score methods, see Heckman, Ichimura, and Todd (1998).

16. The Selected Reserves (SELRES) include members of the Army National Guard, Army Reserve, Air Force Reserve, Air National Guard, Naval Reserve, and Marine Corps Reserve who receive drill pay for attending drills one weekend per month and two weeks during the summer. Excluded are members of other reserve categories (e.g., the Individual Ready Reserve, Standby Reserve) who do not drill monthly or receive drill pay (see U.S. Department of Defense 1986, 1992). For a fuller discussion of the sample design of the RCS, see Defense Manpower Data Center (1987a, 1987b). 17. There were very few reservists with active-duty service outside this age range. Designation of enlisted and officer status among veterans is based on active-duty rank, whereas the designation among nonveteran reservists is based on reserve rank. For the most part, the enlisted and officer tracks are distinct, both within and across the active-duty forces and reserves. Education and training requirements for officers are essentially the same for active-duty and reserve service. For these reasons, nonveteran enlisted reservists provide the most appropriate control group for enlisted veterans, and nonveteran reservist officers the most appropriate control group for veteran officers.

18. The length of service question is in years rather than months. During the Vietnam era some draftees who served in the Vietnam theater would be released with as little as 18 months of service. We would expect these individuals would report two rather than one year of service. The sample of veterans includes those who began service in the reserves, switched to active duty, and then returned to the reserves. This group tended to be older and have somewhat higher earnings (controlling for age) than did other veterans. 
estimation sample 41,413 following deletion of those with hourly earnings below $\$ 2$ or exceeding $\$ 200$. $^{19}$

If veteran status affects labor force participation, then estimation of wage differences among those employed may provide a biased measure of the full veteran treatment effect on earnings, which includes the direct effect via wages and the indirect effect via employment (Angrist 1993, 1998). We conclude that this is not a serious concern for the reservist sample, based on an examination of whether those dropped from the sample due to non-usable earnings information (the decline from 47,907 to 41,413) are disproportionately veteran or non-veteran. Using the sample of 47,907 eligible reservists, a simple linear probability model regressing the probability of being dropped from the estimation sample on veteran status (with controls for age) yielded a coefficient of -.004 (s.e.=0.0035), indicating that sample attrition (and being out of the labor force) is not strongly correlated with veteran status. A similar analysis for officers produced a coefficient on veteran status of 0.001 (s.e. $=0.0066)$.

\section{B. Descriptive Comparison of the Veteran and Nonveteran Samples}

As seen in Table 1, mean hourly earnings in 1992 dollars are \$18.41 among veterans and \$14.94 among nonveterans. The unadjusted mean log wage differential is 0.2387 or a 27.0 percent veteran wage advantage. The wage difference primarily represents an average 6 year age difference between the two groups, veterans averaging 39.0 years and nonveterans 32.9 years, as well as a sizable veteran wage advantage among officers (examined subsequently). ${ }^{20}$ Other differences exist besides a higher wage and age. Veterans have more average schooling, are more likely to be married and have children, are less likely to work part time, and are more likely to be employed in the public sector. Public sector employment is very high for both sets of reservists -- 42.4 percent among veterans and 32.8 percent among nonveterans, as compared to 17.5 percent among all wage and salary workers in 1992 (U.S Bureau of Labor Statistics 1993, p. 235).

Confidence in the simple matching approach in which veteran reservists are compared to nonveteran reservists of the same age rests on there being small differences in measurable (and unmeasurable) non-age characteristics (Meyer 1995). In Table 1, we have constructed age-adjusted means in order to make such a

19. The officer sample prior to deletions is 15,782 . The following groups were deleted sequentially: female (leaving $11,839)$, Coast Guard $(11,302)$, missing age $(11,248)$, those below age 21 or above $59(11,198)$, missing earnings or hours worked $(10,107)$, and hourly earnings below $\$ 2$ or exceeding $\$ 200(10,062)$.

20. The age difference would be larger were we to include reservists under age 21 , almost all of whom are nonveterans. 
comparison. In the third column, age-adjusted nonveteran means have been constructed by calculating the mean value of each characteristic (log wage, education, etc.) at each age between 21 and 59, and then taking the weighted average where the age weights are based on the veteran age distribution. In column 4 and 5 we present the veteran-nonveteran differentials and t-ratios for these age-adjusted means. ${ }^{21}$ Age-adjusted differences are small, providing strong support for our matching approach. Veterans have about 0.25 years more schooling (and 0.25 less potential experience), but these are likely to be outcomes of military service (Angrist 1993). Differences in marital status, number of children, part-time status, and even public sector employment are largely inconsequential, even where statistically significant.

A difference that is sizable is the proportion African-American, being 5.6 percentage points greater among veterans (2.6 percent absent age adjustment). Although race affects the likelihood of active-duty service, standard earnings equation regressions indicate that it is not a significant determinant of wages among our reservist sample. In what follows, results are presented separately by race as well as pooled.

In the bottom portion of Table 1, we provide similar evidence for the enlisted sample, which we subsequently conclude provides a stronger basis for the matched comparison group method. Previous conclusions continue to hold for the enlisted sample, with age-adjusted differences in most characteristics being small. A variable that is unmeasured in the CPS and Census is the proportion of reservists whose father served on active-duty, a variable available in 1986 for virtually all our estimation sample. A very high percentage of reservists' fathers served on active duty, 59 percent among the older veteran sample and 61 percent among the younger nonveteran sample of reservists. Following age-adjustment for age, the pattern flips, with veteran parental service being 2.3 percentage points higher than for nonveterans. The obvious point is that such differences among reservists are likely to be small as compared to the difference in parental service that exists among the general population of veterans and nonveterans. ${ }^{22}$ AFQT scores are available for a small sample of enlisted reservists. The veteran mean of AFQT is a bit higher than for nonveterans, while the age-adjusted means are nearly identical. The similarity in AFQT scores further increases confidence in the

21. The differential calculation is equivalent to (5), which takes the mean difference by age, multiplies each difference by the proportion of veterans who are that age, and sums across ages. 
appropriateness of the matched nonveteran reservist comparison group. ${ }^{23}$

\section{Estimates of the Overall Veteran Treatment Effect}

In Table 2, alternative measures of the average veteran treatment effect are presented. We first summarize results for the full sample and then turn to differences in veteran treatment effects by rank, race, and time period. The large 0.239 unadjusted log wage advantage among veterans is largely accounted for by age. The age-adjusted mean differential, as measured by equation (5), is 0.033 (s.e. $=0.0055)$. This suggests a small, albeit statistically significant, veteran wage advantage across the full sample of reservists.

The age-adjusted differential can be compared to results using regression analysis, where the weighting scheme is less transparent. A sparse regression with only age controls results in a veteran coefficient of 0.028 (s.e. $=0.0056$ ), close to the age-adjusted mean differential of 0.033 . Addition of a standard set of regressors cuts in half the differential, to 0.014 (s.e.=0.0054). If the small differences in schooling and other characteristics are the result of active-duty service, the standard wage regression estimate of the differential is not the preferred approach for estimating the veteran effect.

Finally, we show results using a propensity score matching method. A veteran status logit equation is first estimated as a function of age (and its square and cube) and race. All observations are sorted into deciles based on their propensity scores (i.e., the conditional probability of veteran status). Each veteran is then matched randomly to a nonveteran in the same decile and assigned a "donor" wage. For the sample of veterans, we calculate the mean log wage differential between each veteran's actual and counterfactual nonveteran wage. This provides a measure of the veteran treatment effect. The imputation procedure is conducted 100 times. Table 2 presents the mean differential and standard deviation across the 100 rounds. ${ }^{24}$

The propensity score wage differential is 0.047 , larger than the age-adjusted mean differential or age-

22. We know that the proportion of veterans in the general population of older males is much smaller than 60 percent. Thus the statement in the text holds as long as rates of parental service do not differ markedly among military veterans who are reservists and not reservists.

23. AFQT is available for a group of RCS reservists sampled in both 1986 and 1992. In a standard wage regression the AFQT coefficient is positive and marginally significant. Inclusion of AFQT has no effect on the veteran coefficient. 24. Propensity score matching is conducted using PROC MI (multiple imputation) in SAS 8.1. When matching is done within quintiles rather than deciles, generating less precise matches with respect to age, wage differential estimates are a bit larger. In results not shown, we also used a multiple hot-deck matching procedure in which each veteran is randomly matched to a reservist nonveteran of identical age. For each data set (i.e., match) we calculated the difference in means between observed veteran log wages and log wages of their matched nonveteran donors. As expected, our mean hotdeck differentials are nearly identical to the age-adjusted mean differentials shown in Tables 1-3. 
only regression measure. If we are correct that age constitutes the principal difference between the veteran and nonveteran samples, our propensity score match method provides a less precise matching on age than the alternative methods. If we were concerned about selectivity bias in the reservist sample and possessed good predictors of veteran status among the reservist population (apart from age), we would place greater weight on the propensity score matching differentials. Absent these conditions, we emphasize the methods where we have accounted most completely for age.

The initial results in the top line of Table 2 suggest average treatment effects of active-duty military service on civilian earnings that are small (about 3 percent) but positive. This conclusion applies directly to the sample of reservists (measure $\Delta_{3}$ ), but as argued above, might also approximate $\Delta_{2}$, the average treatment effect of active-duty service among the larger population of all veterans. The veteran effects for the full sample, however, reflect a mix of results across reservists of different rank (officer versus enlisted), race, and time period of service. As we show below, differences in veteran effects with respect to rank and race turn out to be important. Thus, prior to drawing inferences regarding the effects of active-duty service, we examine the RCS evidence at a more disaggregated level.

\section{Differentials by Rank, Race, and Era}

The effects of military service on civilian earnings need not be uniform across different groups of veterans. Much of the literature finds that military service is more advantageous for African-Americans than for whites, while results with respect to period of service are less clear-cut. Most prior studies are unable to distinguish between veterans who served as officers or as enlisted personnel. Information available in the RCS is well suited to examine differences in veteran effects by race, time period, rank, and branch of service.

Readily evident in Table 2 is a substantial difference in results for enlisted personnel and officers. Enlisted personnel (ignoring race and time period) effectively display no veteran treatment effect, as measured by the age-adjusted differential (0.001) and the age-based regression (0.001) shown in Table 2. The positive veteran effect of 3 percent seen for the pooled sample is driven entirely by the sizable $0.10 \log$ wage advantage among officers. Apart from what these results imply about the returns to military service, an

obvious implication is that estimation of veteran effects should distinguish between enlisted personnel and officers, something not possible using the CPS, Census, and other standard data sets. 
More problematic is interpretation of the large officer wage advantage. Is this a real treatment effect or does it reflect unmeasured skill differences between reservist officers with and without active-duty service? Good arguments exist for each interpretation. Junior officers in the active military are given a great deal of responsibility and authority early in their military careers (compared to the civilian experience counterfactual), often commanding a large number of people in their first few years of active duty. Leadership skills such as these no doubt are valued by civilian employers. Reservist officers, in contrast, work just 34 days a year at their military jobs and accumulate leadership skills far more slowly.

Unmeasured skill differences are also likely to be important. Among veteran reservist officers, many have entered the military via the highly competitive service academies (at West Point, Annapolis, and Colorado Springs) or received ROTC scholarships. The service academies and ROTC programs pay college costs (including a stipend) and acceptance into these programs require high test scores, good grades, recommendations from teachers and others, and evidence of leadership potential (Eitelberg et al. 1992). Relatively few nonveteran officers enter the reserves via the service academies or ROTC scholarship routes. So not only do veteran officers tend to be those selected through a highly competitive process, but they also have received high quality training at the service academies. Therefore, the large veteran wage differential among reservist officers is likely to reflect in part non-controlled ability differences between the treatment and comparison groups. The difficulty in interpreting results for officers reinforces our previous conclusion that studies unable to distinguish between officers and enlisted personnel are inherently limited. In what follows, attention is focused primarily on the enlisted rather than the combined RCS sample.

Separate results by race are also examined. White (and other) enlistees exhibit no significant effect of veteran status on earnings, with estimates ranging from roughly minus $1 / 2$ to minus 1 percent. AfricanAmerican enlistees, on the other hand, realize veteran treatment effects of about 5 percent following control for age. The RCS sample of reservists reinforces previous results in the literature indicating positive returns of military service for African-Americans. Because the reserves have entrance requirements identical to active-duty service, the RCS estimates for African-Americans are unlikely to be greatly affected by unmeasured quality differences between veterans and nonveterans, an important concern in studies using the CPS and Census. In short, the positive relationship between active-duty military service and civilian earnings 
for African-Americans appears to be causal.

Table 2 also provides results for enlisted personnel broken down by whether veterans served during the draft era (defined as active-duty service through 1972) or all volunteer force (AVF) era (service beginning after 1972). We include all reservist nonveterans in the comparison group, making matching or control for age essential for a meaningful comparison between veterans and nonveterans. ${ }^{25}$ Among white enlisted personnel, veteran differentials very close to zero are found during the draft-era period, while small negative differentials are found for the AVF period (about minus 2 percent and marginally significant). The small negative returns observed for white veterans serving during the AVF period are consistent with results in Bryant et al. (1993) and Angrist (1998).

A similar service period pattern is found among African-American enlistees, with veteran effects of 68 percent for the draft-era and 4 percent for AVF service. Although estimates for both racial groups suggest that returns to active-duty service have become less favorable over time, large standard errors, particularly for the African-American sample, preclude strong inferences from being drawn.

In sum, results in Table 2 indicate clear differences in the effects of military service between reservist officers and enlisted personnel and by race. Veteran treatment effects are essentially zero among enlisted personnel, whereas veteran officers display a substantial earnings advantage as compared to nonveteran officers. Military service provides positive returns for African-Americans enlistees, but a small penalty for white enlistees. The effects of active-duty service during the AVF period appears to be less favorable than during the earlier draft era period, although such differences are small. ${ }^{26}$

\footnotetext{
25. The alternative is to create separate control groups based on the year in which nonveterans entered the reserves. Besides creating a less intuitive counterfactual, segmenting in this manner creates small age-specific control group samples within some subgroups. If we adopt this approach, unadjusted differentials change substantially owing to differences in the age distribution of the control groups. Age-adjusted differentials are largely similar to those shown. 26. To preserve space, we do not present two additional sets of results. First, we examined veteran effects based on branch of active-duty service (using a common control group), information not available in most data sets. During the AVF period, branch was selected by enlistees. During the conscription era, draftees were assigned to the Army along with volunteers, whereas the other service branches consisted entirely of volunteers. The approximately zero average treatment effect among enlisted personnel reflects a mix of an earnings disadvantage among the large group of Army veterans, offset by small wage advantages among Navy and Marine Corp veterans and a large wage advantage among Air Force veterans. We do not know the extent to which these results reflect true differences in treatment effects versus unmeasured differences in veterans by branch not controlled for by our use of a common comparison group. Second, we examined the impact of transferable military training on civilian earnings by identifying veterans who have a common active-duty, reserve duty, and civilian occupations (this measure was necessitated by the data). As found in previous
} 


\section{E. Wage Differences for Vietnam Veterans}

Although a quarter century has passed since the end of the Vietnam conflict, interest in the experiences of Vietnam veterans remains strong. The nature of the conflict, the use of conscription to meet the growing manpower requirements, the lack of public support for the war, and the treatment of returning veterans were factors conditioning veterans' actual experiences and others' perceptions of this group. In addition, Vietnam veterans have suffered from numerous service-connected psychological and medical problems, including high rates of drug and alcohol abuse, depression, mental problems, arrests and convictions, and post-traumatic stress disorder. Thus, it has appeared that this group was especially disadvantaged in the labor market, and some (but not all) prior research supports this suspicion. ${ }^{27}$

Although the Vietnam era officially ended in 1975, we focus our analysis on those who entered active-duty service between 1964 and 1972. The military shifted to an all-volunteer force in 1973 (no men were drafted after 1972), all U.S. combat units had left South Vietnam by August 1972, bombing of North Vietnam halted December 30, 1972, and all U.S. troops left Vietnam by March 1973 following the Paris Peace Treaty of January 1973 (Karnow 1983). By focusing on earnings in 1986 or 1992, we measure only the long-run labor market effects of Vietnam-era military service.

We observe wage differences between reservists who served on active duty during the Vietnam era and reservists who did not serve. In some doubt are whether results among the reservist population are representative of the average treatment effect among the larger population of all Vietnam-era veterans. In general, the reservist sample should include individuals roughly similar to non-reservist veterans who voluntarily entered the military, given that both groups have demonstrated an interest in the military. We are less willing to argue this for the Vietnam-era during which large numbers of veterans would not have served (as draftees or volunteers) had there not been an increase in force size and a draft. Moreover, the reserve population is unlikely to include either veterans affected most deleteriously by Vietnam, or some of the more

studies (Mangum and Ball 1989), veterans whose civilian occupations are similar to their military occupations realize higher earnings than do other veterans.

27. As late as 1985 , Vietnam veterans displayed higher unemployment rates and lower participation rates than nonveterans (Cohany 1987). Evidence from the September 1993 CPS veteran supplement indicates little difference in unemployment or labor force participation between Vietnam-theater veterans, non-theater Vietnam-era veterans, and nonveterans ages 35-54. Nearly 9 in 10 Vietnam-era veterans were ages 35-54 in 1993 (U.S. Bureau of Labor Statistics 
highly skilled individuals subject to the draft (these individuals are underrepresented in both the treatment and controls groups). Although the bias cannot be unambiguously signed, it is reasonable to believe that were there large negative effects from Vietnam-era service (as suggested by Angrist 1990), wage differentials observed among the reserve population would understate the average Vietnam-era treatment effect.

The RCS data do not directly identify whether veterans served in the Vietnam theater or whether they enlisted or were inducted. However, during this period draftees served two years, whereas volunteers served three years (Angrist 1989). Those who enlisted before receiving an induction notice had more control over the branch in which they served and a lower likelihood of serving in Vietnam. Thus, we differentiate between Vietnam-era veterans who served two years or less and those who served more. Those in the first group (labeled "draftees") are more likely to have been drafted and to have served in Vietnam, while those in the second group (labeled "volunteers") are more likely to have volunteered and to have served elsewhere. ${ }^{28}$

The estimates shown in Table 3, panel A, indicate that enlisted Vietnam-era veterans from the entire 1964-72 Vietnam-era period earned $-0.015 \log$ points or $1 \frac{1}{2}$ percent less than their nonveteran reservist peers. Estimates based on age-weighted means and age regression differentials are the same. This small impact reflects a mix of veteran effects that differ by race. In panel B, we find a modest wage penalty of -0.023 for whites and others. By contrast, the relatively small sample of African-American Vietnam-era veterans (shown in panel C) realized an average wage advantage of just over 5 percent (with a standard error of 0.03 ). In panels $\mathrm{B}$ and $\mathrm{C}$ of Table 3, we differentiate between Vietnam-era veterans likely to have been draftees and those who volunteered, the latter including true and induced volunteers. Among white "draftees" evidence of a wage penalty of about 5 percent is found. No substantial penalty is found for other groups of Vietnam-era reservist veterans. White "volunteers" display a small (and insignificant) wage disadvantage of about -0.015 . African-American veterans serving during the Vietnam era continue to display a wage advantage - about 0.07 among "volunteers" and a small (and insignificant) 0.03 among "draftees". The

1994). Apart from the labor market, Hearst et al. (1986) find that men with birth dates that made them draft eligible during 1970-72 had higher mortality (in particular, suicide and motor vehicle accidents) than those not draft eligible. 28. Note that most of those who entered the military were not drafted. During the peak of the Vietnam mobilization in 1968, however, 40 percent of new accessions were drafted (U.S. Bureau of the Census 1975, p. 327). It has been estimated that as high as 50 percent of volunteers (or 30 percent of all accessions) were "reluctant volunteers" who enlisted to avoid conscription into the Army, a combat specialty, and a tour of duty in Vietnam. 
finding that white and black draftees fared worse than volunteers presumably reflects a combination of deleterious effects of service in the Vietnam theater (which was more likely for draftees), higher valued military training received by volunteers than draftees, and higher opportunity costs for draftees than for volunteers.

Our estimated wage effects of service during the Vietnam era are far smaller than those computed by Angrist (1990), who relies on date of birth to instrument military service and obtains estimates suggesting a 15 percent wage penalty among white veterans whose service resulted from the draft lottery. To align our set up more closely with Angrist, we create an enlisted veteran sample from the RCS composed of those who were in the same Vietnam-era birth cohorts as in the Angrist study (1950-52) and who entered the military during the 1970-72 draft lottery period. The comparison group includes all nonveteran enlisted reservists born during 1950-52. These results are shown in the two columns to the far right in Table 3. In general, results for the 1950-52 cohorts entering the military during 1970-72 (columns 3 and 4) are similar to our previous results for all cohorts during the entire Vietnam-era period (columns 1 and 2).

The draft lottery result that should correspond most closely to Angrist is the result for white draftees. Here we find an approximate 5 percent wage penalty for active duty Vietnam-era service, far less than the 15 percent estimated by Angrist. ${ }^{29}$ For reasons discussed previously, it seems likely that Vietnam-era treatment effects among reservists are likely to understate treatment effects for the more general population of induced draftees during the 1970-72 lottery period. Given the very different nature of our data and methods from those of Angrist, it is difficult to know if our focus on reservists is the principal explanation for the difference in estimates. The similarity in our estimates for the draft lottery cohorts and for the entire Vietnam-era period (columns 3-4 versus 1-2) suggests that Angrist's draft lottery results might be generalized to white draftees throughout the entire Vietnam era. This is an interesting result because ground combat had wound down so that those entering the military during 1970-72 were less likely than were earlier cohorts to have been assigned to Vietnam or to have seen combat. It suggests that the negative veteran effects found for draftees throughout the Vietnam-era resulted primarily from the distortion of choices brought about by a draft, and not the direct 
effects from combat or service in the Vietnam theater. ${ }^{30}$

\section{Summary and Conclusions}

Central to research trying to estimate the effects of military service on earnings has been the identification of the appropriate counterfactual - what the earnings of veterans would have been had they not served in the military. This study relies on data from civilian workers linked by affiliation in the military reserves, roughly 60 percent of whom are active-duty veterans and the remainder of whom are nonveterans. Following control for age differences, the reservist data permit a matched comparison group design in which important forms of selection by individuals and the military are controlled. Although veteran-nonveteran wage differences among reservists most directly measure the average treatment effect of active-duty service among the reservist population, we have argued that estimates may provide a reasonable approximation of treatment effects among the larger population of all military veterans.

Estimates of treatment effects are obtained using weighted mean wage differences by age (using the veteran age distribution as weights), regression analysis with sparse and dense specifications, and propensity score methods. Across veterans of all time periods, races, and ranks, we find a small but positive 3 percent wage advantage among veterans. If the analysis is restricted to enlisted personnel, the average treatment effect is effectively zero. In short, among the population of reservists, active-duty military service on average appears to have little causal impact on subsequent civilian earnings, a year of military service contributing no more or less than a year of civilian experience. This finding dovetails with the conclusion reached by Angrist (1998), although he notes that veterans receive higher earnings than their nonveteran counterparts while in the military, are somewhat more likely to be employed, and increase subsequent investment in schooling.

29. Limitation of the control group to nonveterans who first entered the reserves during 1970-72 (and remain there through 1986 or 1992) results in more negative veteran wage effects among the draft lottery cohorts. This rather peculiar control group is unlikely to represent the appropriate counterfactual.

30. A referee suggests that the findings could alternatively be explained by equivalent civilian treatment (presumably discriminatory) of all Vietnam-era veterans. The similarity of results for the draft lottery and full Vietnam-era do not support the conjecture by Heckman (1997, p. 450n) that: “... knowing how military service affects earnings during the period of a lottery would not be informative about how military service affected earnings during the period of an ordinary draft." Among other things, Heckman argues that the greater certainty associated with a lottery than with a "capricious" draft lowers investment risk and increases the value to employers of young men not likely to be drafted. The suggestion is that conscription prior to the draft-lottery period caused lower earnings among those not drafted as well as drafted. 
Although the average effect of veteran status on wages is small, there is substantial variety in results. As compared to a zero treatment effect among enlisted personnel, officers realize a substantial wage advantage compared to nonveteran reservist officers. An implication of these results is that analyses that mix officers and enlisted personnel overstate the effects of military service for the vast majority of veterans who were not officers. A common view is that the military provides African-Americans with a high return on training and a particularly effective "bridge" between high school and civilian work (or subsequent schooling followed by work). Among enlisted personnel, evidence is found for large positive returns to active-duty service for African-Americans, as compared to a small negative return among the nonblack population.

Overall wage differences between enlisted veteran and nonveteran reservists of the Vietnam era are small, and likely understate the negative effects of Vietnam-era service for the broader population of veterans outside the reserves. We find clear-cut wage penalties among white veterans most likely to have been draftees, although not so large as those found in the frequently-cited paper by Angrist (1990). Similar results are found for the entire Vietnam-era period and for just those cohorts subjected to the 1970-1972 draft lottery, the group examined by Angrist (1990).

The finding here of a small overall effect of military service echoes that of Angrist (1998) in his comprehensive study of the AVF period. Indeed, the many areas of agreement between this and earlier studies suggest not only that an analysis of reservists provides an effective and simple method for accounting for individual and military selection, but also that selection effects on net are modest. Selection effects have been shown to be important during the World War II and Vietnam wartime periods when there were substantial expansions in force size and use of the draft (Angrist and Krueger 1994; Angrist 1990). During periods where force size has not been so large and service largely voluntary, selection effects on net have not proved so important, with selection by the military and by applicants largely canceling out. Selection by the military largely eliminates the lower end of the "ability" distribution, while selection by applicants reduces recruits coming from the high end (for a similar two-sided selection model applied to union wage effects, see Card 1996). The ability distribution among veterans is more homogeneous than among nonveterans, but average differences may be small and selectivity bias not so serious a problem. Based on studies that do and 
do not account for selectivity, one arrives at the conclusion that the impact of active-duty military service on civilian earnings is slightly negative or zero for white enlistees and modestly positive for African-Americans. 


\section{References}

Angrist, Joshua D. 1989. "Using the Draft Lottery to Measure the Effect of Military Service on Civilian Labor Market Outcomes." In Research in Labor Economics, Vol. 10, ed. Ronald Ehrenberg, 265-310.

Greenwich, CT: JAI Press.

1990. "Lifetime Earnings and the Vietnam Era Draft Lottery: Evidence From Social Security

Administration Records." American Economic Review 80(3): 313-36.

. 1993. "The Effect of Veterans Benefits on Education and Earnings." Industrial and Labor Relations Review 46(4): 637-52.

1998. "Estimating the Labor Market Impact of Voluntary Military Service on Earnings Using Social Security Data on Military Applications.” Econometrica 66(2): 249-88.

Angrist, Joshua D. and Alan B. Krueger. 1994. "Why Do World War II Veterans Earn More Than Nonveterans? Journal of Labor Economics 12(1): 74-97.

. 1999. "Empirical Strategies in Labor Economics." In Handbook of Labor Economics, Vol. 3A, eds.

Orley Ashenfelter and David Card, 1277-366. Amsterdam: Elsevier Science.

Bell, Stephen H., Larry L. Orr, John D. Blomquist, and Glen G. Cain. 1995. Program Applicants as a Comparison Group in Evaluating Training Program: Theory and a Test. Kalamazoo, MI: Upjohn Institute for Employment Research.

Berger, Mark C. and Barry T. Hirsch. 1983. "The Civilian Earnings Experience of Vietnam-Era Veterans." Journal of Human Resources 18(4): 455-479.

Bound, John. 1989. "The Health and Earnings of Rejected Disability Insurance Applicants." American Economic Review 79(3): 482-503.

Bound, John, David A. Jaeger, and Regina M. Baker. 1995. "Problems with Instrumental Variables Estimation When the Correlation Between the Instruments and the Endogenous Explanatory Variable is Weak." Journal of the American Statistical Association 90(430): 443-50.

Bryant, Richard and Allen Wilhite. 1990. "Military Experience and Training Effects on Civilian Wages." Applied Economics 22(1): 69-81.

Bryant, Richard, V.A. Samaranayake, and Allen Wilhite. 1993. "The Effect of Military Service on the Subsequent Civilian Wage of the Post-Vietnam Veteran." Quarterly Review of Economics and Finance 33(1): 15-31.

Card, David. 1996. "The Effect of Unions on the Structure of Wages: A Longitudinal Analysis." Econometrica 64 (4): 957-79.

. 1999. "The Causal Effect of Education on Earnings." In Handbook of Labor Economics, Volume 3A, eds.Orley Ashenfelter and David Card, 1801-63. Amsterdam: Elsevier Science.

Cohany, Sharon. 1987. "Labor Force Status of Vietnam-era Veterans.” Monthly Labor Review 110(2): 11-17.

Cowpers, Diane, Lynne Heltman, and Stephen Dienstfrey. 1994. The Concept of Veteran Status in the U.S. Decennial Censuses: 1960-1990. Princeton, NJ: Association of Public Data Users. 
Dehejia, Rajeev H. and Sadek Wahba. 1998. "Propensity Score Matching Methods for Non-Experimental Causal Studies.” National Bureau of Economic Research Working Paper 6829, December.

. 1999. "Causal Effects in Non-Experimental Studies: Re-Evaluating the Evaluation of Training Programs." Journal of the American Statistical Association 94: 1053-62.

Defense Manpower Data Center. 1987a. 1986 Reserve Components Survey: Selected Reserve Officer and Enlisted Personnel -- User's Manual and Codebook. Arlington, VA.

. 1987b. Description of Officers and Enlisted Personnel in the U.S. Selected Reserve: 1986.

Arlington, VA.

Eitelberg, Mark J., Janice Laurence, and Dianne Brown. 1992. "Becoming Brass: Issues in the Testing, Recruiting, and Selection of American Military Officers." In Test Policy in Defense: Lessons from the Military for Education, Training, and Employment, eds. Bernard R. Gifford and Linda C. Wing, 79-219. Boston, MA: Kluwer Academic Publishers.

Grissmer David W., Richard J. Buddin, and Sheila N. Kirby. 1989. Improving Reserve Compensation: A Review of Current Compensation and Related Personnel and Training Readiness Issues. Santa Monica, CA: Rand Corporation, R-3707-FMP/RA, September.

Grissmer, David W., Sheila N. Kirby, Richard Buddin, Jennifer Kawata, Jerry Sollinger, and Stephanie Williamson. 1994. Prior Service Personnel: A Potential Constraint on Increasing Reliance on Reserve Forces. Santa Monica, CA: Rand Corporation, MR-362-OSD.

Heckman, James J. 1997. "Instrumental Variables: A Study of Implicit Behavioral Assumptions Used In Making Program Evaluations.” Journal of Human Resources 32(3): 441-62.

Heckman, James J., Hidehiko Ichimura, and Petra E. Todd. 1998. "Matching as an Econometric Evaluation Estimator." Review of Economic Studies 65(2): 261-94.

Heckman, James J., Robert J. LaLonde, and Jeffrey A. Smith. 1999. "The Economics and Econometrics of Active Labor Market Programs." In Handbook of Labor Economics, Vol. 3A, eds. Orley Ashenfelter and David Card, 1865-2097. Amsterdam: Elsevier Science.

Hearst, Norman, Thomas B. Newman, and Stephen B. Hulley. 1986. "Delayed Effects of the Military Draft on Mortality: A Randomized Natural Experiment." New England Journal of Medicine, March 6, 314(10): 620-624.

Jackson, John L. 1986. “Long run Effects of Military Service during the Vietnam War.” In The Changing Labor Market: A Longitudinal Study of Young Men, ed. Stephen M. Hill, 113-31. Lexington, MA: Lexington Books.

Karnow, Stanley. 1983. Vietnam: A History. New York: Viking Press.

LaLonde, Robert J. 1986. "Evaluating the Econometric Evaluations of Training Programs with Experimental Data." American Economic Review 76(4): 604-20.

Mangum, Stephen L. and David E. Ball. 1989. "The Transferability of Military-Provided Occupational Training in the Post-Draft Era." Industrial and Labor Relations Review 42(2): 230-45.

Marquis, M. Susan and Sheila N. Kirby. 1989. Reserve Accessions Among Individuals with Prior Military Service: Supply and Skill Match. Santa Monica, CA: Rand Corporation, R-3892-RA, October. 
Mehay, Stephen L. 1991. "Reserve Participation vs. Moonlighting: Are They the Same?" Defence Economics 2(4): 325-37.

Mehay, Stephen L. and Barry T. Hirsch. 1996. "The Post-Service Earnings of Female Veterans.” Industrial Relations 35(2): 197-217.

Meyer, Bruce D. 1995. "Natural and Quasi-Experiments in Economics." Journal of Economics and Business Statistics 13(2): 151-61.

Myers, Steven Lee. 2000. "Military Reserves are Falling Short in Finding Recruits.” New York Times, August 28.

Phillips, Robert L., Paul J. Andriasani, and Thomas N. Daymont. 1992. "The Economic Returns to Military Service: Race-Ethnic Differences.” Social Science Quarterly 73(2): 340-59.

Rosenbaum Paul R. and Donald B. Rubin. 1983. "The Central Role of the Propensity Score in Observational Studies for Causal Effects." Biometrika 70: 41-55.

Rubin. Donald B. 1987. Multiple Imputation for Nonresponse in Surveys. New York: John Wiley.

Schwartz, Saul. 1986. "The Relative Earnings of Vietnam and Korean-Era Veterans." Industrial and Labor Relations Review 39(4): 564-72.

Smith, Jeffrey A. and Petra Todd. 2000. "Does Matching Overcome LaLonde's Critique of Nonexperimental Estimators?” Penn Institute for Economic Research (PIER) Working Paper No. 01-035, November.

U.S. Bureau of the Census. 1975. Statistical Abstract of the United States: 1975. Washington, D.C.: USGPO.

U.S. Bureau of Labor Statistics. 1993. Employment and Earnings (January). Washington, D.C.: USGPO.

U.S. Bureau of Labor Statistics. 1994. "Employment Situation of Vietnam-Era Veterans.” News Release, October 21.

U.S. Department of Defense. 1986. Official Guard and Reserve Manpower Strengths and Statistics, Fiscal Year 1986 Summary. Washington, D.C: USGPO.

1992. Official Guard and Reserve Manpower Strengths and Statistics, Fiscal Year 1992 Summary. Washington, D.C: USGPO.

1996. The Reserve Components of the U.S. Armed Forces. Washington, D.C: Office of the Assistant Secretary of Defense for Reserve Affairs, June.

U.S. Department of Veterans Affairs. 1989. 1987 Survey of Veterans. Washington, DC: USGPO, September.

U.S. General Accounting Office. 1997. Military Attrition: DOD Could Save Millions by Better Screening Enlisted Personnel. GAO/NSIAD-97-39. Washington, DC: USGPO, January. 


\section{Table 1: Unadjusted and Age-Adjusted Means for Veteran and Nonveteran Reservists, Selected Variables}

\begin{tabular}{|c|c|c|c|c|c|}
\hline Variables & $\begin{array}{r}\text { Veteran } \\
\text { Means } \\
\end{array}$ & $\begin{array}{r}\text { Nonveteran } \\
\text { Means } \\
\end{array}$ & $\begin{array}{r}\text { Nonveteran } \\
\text { Age-weighted } \\
\text { Means } \\
\end{array}$ & $\begin{array}{r}\text { Age-adjusted } \\
\text { Differentials } \\
\end{array}$ & t-test \\
\hline \multicolumn{6}{|l|}{ Pooled Enlisted-Officer Sample: } \\
\hline Wage $(1992 \$)$ & 18.41 & 14.94 & -- & -- & -- \\
\hline Age & 39.01 & 32.87 & -- & -- & -- \\
\hline Log wage & 2.7001 & 2.4615 & 2.6669 & .0332 & 6.04 \\
\hline Education & 14.37 & 13.59 & 14.03 & 0.34 & 14.76 \\
\hline Experience & 18.62 & 13.25 & 18.96 & -0.33 & -4.54 \\
\hline African-American & 0.141 & 0.129 & 0.097 & 0.044 & 14.67 \\
\hline Hispanic & 0.059 & 0.058 & 0.052 & 0.007 & 3.35 \\
\hline Married, spouse present & 0.783 & 0.645 & 0.797 & -0.014 & -3.72 \\
\hline Separated, widowed, divorced & 0.107 & 0.078 & 0.094 & 0.012 & 4.51 \\
\hline Number children & 1.623 & 1.239 & 1.647 & -0.024 & -1.95 \\
\hline Part-time & 0.069 & 0.106 & 0.061 & 0.008 & 3.68 \\
\hline Public & 0.424 & 0.328 & 0.426 & -0.002 & -0.36 \\
\hline $\mathrm{N}$ & 31,525 & 19,950 & -- & -- & -- \\
\hline \multicolumn{6}{|l|}{ Enlisted Personnel: } \\
\hline Wage $(1992 \$)$ & 16.16 & 13.79 & -- & -- & -- \\
\hline Age & 38.45 & 32.01 & -- & -- & -- \\
\hline Log wage & 2.5842 & 2.3927 & 2.5830 & .0012 & 0.21 \\
\hline Education & 13.47 & 13.06 & 13.27 & 0.20 & 9.89 \\
\hline Experience & 18.96 & 12.92 & 19.16 & -0.19 & -2.26 \\
\hline African-American & 0.169 & 0.140 & 0.110 & 0.060 & 17.11 \\
\hline Hispanic & 0.069 & 0.062 & 0.057 & 0.012 & 4.88 \\
\hline Married, spouse present & 0.763 & 0.620 & 0.781 & -0.018 & -4.17 \\
\hline Separated, widowed, divorced & 0.114 & 0.080 & 0.100 & 0.013 & 4.33 \\
\hline Number children & 1.585 & 1.193 & 1.679 & -0.023 & -1.69 \\
\hline Part-time & 0.075 & 0.114 & 0.066 & 0.010 & 3.77 \\
\hline Public & 0.439 & 0.317 & 0.426 & 0.013 & 2.54 \\
\hline $\mathrm{N}$ & 24,332 & 17,081 & -- & -- & -- \\
\hline \multicolumn{6}{|l|}{ Enlisted subsample (1986 only): } \\
\hline Father served active-duty & 0.590 & 0.606 & 0.567 & 0.023 & 3.83 \\
\hline $\mathrm{N}$ & 16,217 & 10,956 & -- & -- & -- \\
\hline
\end{tabular}

Notes: Data are for male reservists, ages 21-59, sampled in the Reserve Component Surveys (RCS) for 1986 and 1992. Results shown in the top panel are based on a pooled enlisted and officer sample and in the bottom panel on enlisted only. The "Nonveteran Age-weighted Mean" is calculated by summing the nonveteran means by age using veteran age weights. The "Age-Adjusted Differential" is the difference between the veteran mean and the nonveteran age-weighted mean; it measures the within-age mean difference between veterans and noveterans, calculated using the veteran age distribution weights. The t-test is calculated using the age-cell mean values. See the text for complete discussion. 


\section{Table 2: Veteran-Nonveteran Log Wage Differentials: Enlisted and Officer RCS Samples}

$\begin{array}{llllll}\text { Veteran } & & & & \\ \text { Sample Size } & \text { Unadjusted } & \text { Age-Adjusted } & \text { Age-Only } & \text { Standard } & \text { Propensity } \\ \text { (\%Veteran) } & \text { Differential } & \text { Differential } & \text { Regression } & \text { Regression } & \text { Differential }\end{array}$

All Personnel (N=51,475)

$\begin{array}{lllllll}\text { All Eras } & 31,525(61.2 \%) & .2387 & .0332 & .0276 & .0142 & .0473 \\ & & & (.0055) & (.0056) & (.0054) & {[.0052]}\end{array}$

Officers $(\mathrm{N}=10,062)$

$\begin{array}{lllllll}\text { All Eras } & 7,193(71.5 \%) & .2212 & .1027 & .0963 & .0790 & .1280 \\ & & & (.0126) & (.0126) & (.0124) & {[.0121]}\end{array}$

Enlisted $(\mathrm{N}=41,413)$

$\begin{array}{lllllll}\text { All Eras } & 24,332(58.8 \%) & .1916 & .0012 & .0009 & -.0020 & .0126 \\ & & & (.0058) & (.0060) & (.0060) & {[.0070]}\end{array}$

Enlisted Whites and Others $(\mathrm{N}=34,896)$

$\begin{array}{lccllll}\text { All Eras } & 20,212(57.9 \%) & .1824 & -.0070 & -.0092 & -.0095 & .0020 \\ & & & (.0061) & (.0063) & (.0062) & {[.0063]} \\ \text { Draft-era } & 13,999 & .2869 & -.0029 & .0037 & -.0031 & .0074 \\ & & & (.0069) & (.0076) & (.0076) & {[.0082]} \\ \text { AVF } & 6,213 & -.0530 & -.0161 & -.0235 & -.0182 & -.0169 \\ & & & (.0087) & (.0089) & (.0089) & {[.0102]}\end{array}$

Enlisted African-Americans (N=6,517)

\begin{tabular}{|c|c|c|c|c|c|c|}
\hline All Eras & $4,120(63.2 \%)$ & .2524 & $\begin{array}{l}.0498 \\
(.0173)\end{array}$ & $\begin{array}{l}.0534 \\
(.0185)\end{array}$ & $\begin{array}{l}.0463 \\
(.0183)\end{array}$ & $\begin{array}{l}.0593 \\
{[.0247]}\end{array}$ \\
\hline Draft-era & 2,399 & .3873 & $\begin{array}{l}.0580 \\
(.0227)\end{array}$ & $\begin{array}{c}.0784 \\
(.0262)\end{array}$ & $\begin{array}{c}.0577 \\
(.0261)\end{array}$ & $\begin{array}{l}.0767 \\
{[.0312]}\end{array}$ \\
\hline AVF & 1,721 & .0643 & $\begin{array}{l}.0385 \\
(.0211)\end{array}$ & $\begin{array}{l}.0386 \\
(.0219)\end{array}$ & $\begin{array}{l}.0363 \\
(.0217)\end{array}$ & $\begin{array}{c}.0364 \\
{[.0187]}\end{array}$ \\
\hline
\end{tabular}

Notes: Shown are log wage differentials between male veterans and nonveterans in the Reserve Component Surveys (RCS) for 1986 and 1992, ages 21-59. N is the combined veteran and nonveteran sample size. Veteran sample size is shown in column 1. The Draft-era and AVF results are based on a common nonveteran comparison group. The "Unadjusted Differential" represents the mean of log wages for veterans minus the mean for nonveterans. The "Age-Adjusted Differential" is described in the text and measures the within-age mean log wage difference between veterans and nonveterans, calculated using the veteran weighted age distribution. The "AgeOnly Regressions" include a constant, age, age squared, and age cubed in addition to a veteran status dummy (shown in the table). The "Standard Regression" includes the veteran status dummy, plus years of schooling, potential experience and its square (including active-duty service), broad occupation dummies, race and ethnicity dummies, and a year dummy. Numbers in parentheses under the wage differentials are standard errors. The "Propensity Differential" (described in text) uses a logit regression to determine the propensity score (i.e., the conditional probability of veteran status) based on age, age-squared, age-cubed, and race (for results not racespecific). Individuals are ordered into deciles based on their propensity scores. Each veteran is randomly matched to a nonveteran in the same decile and assigned a donor wage. The difference between the veteran's actual wage and the imputed or counterfactual nonveteran wage is averaged across all veterans to form an estimate of the veteran treatment effect. This multiple imputation procedure is repeated 100 times. Shown is the mean veterannonveteran $\log$ wage differential across the 100 rounds, with the standard deviation shown in brackets. 
Table 3: Log Wage Differentials for Enlisted Vietnam-Era Veterans

\begin{tabular}{|c|c|c|c|c|}
\hline & $\begin{array}{l}\text { Vietnam Era } \\
(1964-1972)\end{array}$ & $\begin{array}{l}\text { Vietnam Erc } \\
\text { (1964-1972) }\end{array}$ & $\begin{array}{r}\text { Draft Lottery } \\
(1970-1972\end{array}$ & $\begin{array}{r}\text { Draft Lottery } \\
(1970-1972)\end{array}$ \\
\hline & Age Differential & Age Regression & Age Differential & Age Regression \\
\hline $\begin{array}{l}\text { A. All Vietnam-era Veterans } \\
\qquad(\mathrm{N}=10,136 ; 1,796)\end{array}$ & $\begin{array}{l}-.0148 \\
(.0085)\end{array}$ & $\begin{array}{l}-.0150 \\
(.0088)\end{array}$ & $\begin{array}{l}-.0041 \\
(.0179)\end{array}$ & $\begin{array}{l}-.0053 \\
(.0178)\end{array}$ \\
\hline $\begin{array}{l}\text { B. White and Other } \\
\qquad(\mathrm{N}=8,415 ; 1,424)\end{array}$ & $\begin{array}{l}-.0233 \\
(.0088)\end{array}$ & $\begin{array}{l}-.0234 \\
(.0091)\end{array}$ & $\begin{array}{l}-.0145 \\
(.0189)\end{array}$ & $\begin{array}{l}-.0172 \\
(.0188)\end{array}$ \\
\hline $\begin{array}{l}\text { Volunteer, White and Other } \\
(\mathrm{N}=6,262 ; 1,086)\end{array}$ & $\begin{array}{l}-.0145 \\
(.0093)\end{array}$ & $\begin{array}{l}-.0153 \\
(.0096)\end{array}$ & $\begin{array}{l}-.0044 \\
(.0204)\end{array}$ & $\begin{array}{l}-.0054 \\
(.0203)\end{array}$ \\
\hline $\begin{array}{l}\text { Draftee, White and Other } \\
(\mathrm{N}=2,153 ; 338)\end{array}$ & $\begin{array}{l}-.0490 \\
(.0130)\end{array}$ & $\begin{array}{l}-.0481 \\
(.0133)\end{array}$ & $\begin{array}{l}-.0469 \\
(.0310)\end{array}$ & $\begin{array}{l}-.0499 \\
(.0307)\end{array}$ \\
\hline $\begin{array}{l}\text { C. African-American } \\
\qquad(\mathrm{N}=1,721 ; 372)\end{array}$ & $\begin{array}{l}.0574 \\
(.0314)\end{array}$ & $\begin{array}{l}.0530 \\
(.0322)\end{array}$ & $\begin{array}{l}.0917 \\
(.0544)\end{array}$ & $\begin{array}{l}.0776 \\
(.0550)\end{array}$ \\
\hline $\begin{array}{l}\text { Volunteer, African-American } \\
(\mathrm{N}=1,035 ; 251)\end{array}$ & $\begin{array}{c}.0753 \\
(.0338)\end{array}$ & $\begin{array}{l}.0686 \\
(.0346)\end{array}$ & $\begin{array}{l}.0972 \\
(.0592)\end{array}$ & $\begin{array}{l}.0782 \\
(.0606)\end{array}$ \\
\hline $\begin{array}{l}\text { Draftee, African-American } \\
(\mathrm{N}=686 ; 121)\end{array}$ & $\begin{array}{l}.0304 \\
(.0384)\end{array}$ & $\begin{array}{l}.0305 \\
(.0403)\end{array}$ & $\begin{array}{l}.0799 \\
(.0755)\end{array}$ & $\begin{array}{l}.0704 \\
(.0774)\end{array}$ \\
\hline
\end{tabular}

Notes: Results based on 1986 and 1992 RCS. See the text for a detailed description of the samples and measures and the note in Table 2 for a brief description of the age-adjusted differential and age-only regression. The listed $\mathrm{N}$ to the left of the semicolon represents the sample size of veterans for the full Vietnam-era period, while $\mathrm{N}$ to the right of the semicolon is the sample size of veterans in the 1950-52 draft lottery birth cohorts who enlisted in active-duty service during 1970-72. The comparison group includes all nonveteran reservists over the same age range as veterans. 


\section{IZA Discussion Papers}

\begin{tabular}{|c|c|c|c|c|}
\hline No. & Author(s) & Title & Area & Date \\
\hline 725 & S. Habermalz & An Examination of Sheepskin Effects Over Time & 1 & $02 / 03$ \\
\hline 726 & S. Habermalz & $\begin{array}{l}\text { Job Matching and the Returns to Educational } \\
\text { Signals }\end{array}$ & 1 & $02 / 03$ \\
\hline 727 & $\begin{array}{l}\text { M. Raiser } \\
\text { M. Schaffer } \\
\text { J. Schuchardt }\end{array}$ & Benchmarking Structural Change in Transition & 4 & $02 / 03$ \\
\hline 728 & $\begin{array}{l}\text { M. Lechner } \\
\text { J. A. Smith }\end{array}$ & What is the Value Added by Caseworkers? & 6 & $02 / 03$ \\
\hline 729 & $\begin{array}{l}\text { A. Voicu } \\
\text { H. Buddelmeyer }\end{array}$ & $\begin{array}{l}\text { Children and Women's Participation Dynamics: } \\
\text { Transitory and Long-Term Effects }\end{array}$ & 3 & $02 / 03$ \\
\hline 730 & $\begin{array}{l}\text { M. Piva } \\
\text { M. Vivarelli }\end{array}$ & $\begin{array}{l}\text { Innovation and Employment: Evidence from } \\
\text { Italian Microdata }\end{array}$ & 2 & $02 / 03$ \\
\hline 731 & $\begin{array}{l}\text { B. R. Chiswick } \\
\text { N. DebBurman }\end{array}$ & $\begin{array}{l}\text { Educational Attainment: Analysis by Immigrant } \\
\text { Generation }\end{array}$ & 1 & $02 / 03$ \\
\hline 732 & $\begin{array}{l}\text { A. Frank } \\
\text { A. Ichino }\end{array}$ & Clean Evidence on Peer Pressure & 5 & $03 / 03$ \\
\hline 733 & $\begin{array}{l}\text { S. Wolter } \\
\text { S. Denzler }\end{array}$ & $\begin{array}{l}\text { Wage Elasticity of the Teacher Supply in } \\
\text { Switzerland }\end{array}$ & 2 & $03 / 03$ \\
\hline 734 & S. Wolter & Sibling Rivalry: A Six Country Comparison & 2 & $03 / 03$ \\
\hline 735 & $\begin{array}{l}\text { R. Desmet } \\
\text { A. Jousten } \\
\text { S. Perelman } \\
\text { P. Pestieau }\end{array}$ & $\begin{array}{l}\text { Micro-Simulation of Social Security Reforms in } \\
\text { Belgium }\end{array}$ & 3 & $03 / 03$ \\
\hline 736 & $\begin{array}{l}\text { I. Bolvig } \\
\text { P. Jensen } \\
\text { M. Rosholm }\end{array}$ & The Employment Effects of Active Social Policy & 6 & $03 / 03$ \\
\hline 737 & $\begin{array}{l}\text { A. L. Booth } \\
\text { M. Francesconi } \\
\text { G. Zoega }\end{array}$ & $\begin{array}{l}\text { Unions, Work-Related Training, and Wages: } \\
\text { Evidence for British Men }\end{array}$ & 3 & $03 / 03$ \\
\hline 738 & V. Grossmann & $\begin{array}{l}\text { Managerial Job Assignment and Imperfect } \\
\text { Competition in Asymmetric Equilibrium }\end{array}$ & 1 & $03 / 03$ \\
\hline 739 & M. Fertig & $\begin{array}{l}\text { Who's to Blame? The Determinants of German } \\
\text { Students' Achievement in the PISA } 2000 \text { Study }\end{array}$ & 1 & $03 / 03$ \\
\hline 740 & $\begin{array}{l}\text { B. T. Hirsch } \\
\text { S. L. Mehay }\end{array}$ & $\begin{array}{l}\text { Evaluating the Labor Market Performance of } \\
\text { Veterans Using a Matched Comparison Group } \\
\text { Design }\end{array}$ & 6 & $03 / 03$ \\
\hline
\end{tabular}

An updated list of IZA Discussion Papers is available on the center's homepage www.iza.org. 